\title{
Passengers' Perception Towards Physical Security Measures of Suvarnabhumi Airport Rail Link Service
}

\section{Dr. Chaiyaset Promsri}

\author{
Faculty of Business Administration, Rajamangala University of Technology Phra Nakhon, Thailand \\ Email: Chaiyaset.p@rmutp.ac.th
}

\section{Doi:10.5901/mjss.2015.v6n1p309}

\begin{abstract}
This research aimed to study perceived physical security measures of passengers towards Suvarnabhumi Airport Rail Link service. The specific objectives of this explanatory quantitative study were 1) to describe Airport Rail Link customers in terms of socio-demographic characteristics, decisions of using of service factors, and their perceptions of security measures; 2) to examine significance mean differences between socio-demographic characteristics and frequency of using Suvarnabhumi Airport Rail Link service in evaluating security measures; and 3) to generate implications of research findings to respond physical security measures of Suvarnabhumi Airport Rail Link services. In this research, a 25-item of self-administered questionnaire developed by Promsri (2009) was used for data collection. There were three parts of questionnaire to assess security measures. Physical security measures were measured by Suvarnabhumi Airport Rail Link customers using five dimensions of Security Risk Assessment Questionnaire, which consisted of access control system, CCTV and VDO system, communication and public relations system, protective lighting system, and personal control and security guard system. Samples of 400 respondents participated in data collection. The internal reliability of scale showed a Cronbach's alpha of 0.87 . Results showed that the level of overall assessment of security measures of Suvarnabhumi Airport Rail Link were in a high level ( $\bar{x}=3.56$ ) The analysis of independent $t$-test indicated no significant mean difference between male and female passengers and for marital status in evaluating security measures of Suvarnabhumi Airport Rail Link service. Analysis of variance (ANOVA) revealed statistically significant differences among passengers in different age groups, educational levels, and frequencies of using service to perceived security measures of Suvarnabhumi Airport Rail Link service. Recommendations for research implementations for Suvarnabhumi Airport Rail Link of Thailand were to install X-ray equipment (Walk through Metal Protector) as a detective assistance for security management, and to strictly check passengers when enter to the Suvarnabhumi Airport Rail Link terminal or station. Future research recommendations were also discussed.
\end{abstract}

Keywords: Physical security, Security measures, Security management ,Airport Rail Link, Suvarnabhumi

\section{Introduction}

Public transportation system has increasingly become the key target for multiple attacks. Since 1970, they have been more than 800 attacks on public transportation systems. In past years, public transportation systems in large cities such as London, Paris, Tokyo, Madrid, Moscow, and Mumbai had suffered from terrorist attacks (Armstrong et al., 2008). Research indicated an increase of 20\% of terrorist attacks on public transportation from 1991 to 1998 (Fink, Taylor, and, Loukaitour-Sideris, 2005). Moreover, report of U.S. General Accounting Office (2003) showed that the surface transportation systems worldwide had been terrorist-attacked more than 195 times between 1997-2000. Fink et al. (2005) noted that almost $50 \%$ of attacks on public transportation systems occurred on subways and trains, stations, and rail paths. International surveys related to security of railways transportation have shown the low satisfaction of security measures (Armstrong et al, 2008; Passengerfocus, 2009). There are numerous sources of risks and threats both internally and externally that have the potential to affect the certainty of public transportation system. The manifestation of threats can occur in forms of accidents, contamination, criminal activity, cyber-attack, passenger assault, public mass hysteria, natural disasters, power outrage, system failures, terrorist attack, collateral damage, and riot (The Department of Veterans Affairs, 2000, p. 11). Rail and mass transit systems including subway, elevated train, and airport rail link are being threatened in terms of safety and security as they are susceptible to sabotage, devastation, and other criminal activities that can happen not only in the terminal or the station, but also on the way between station to station, which most of the paths are in the open system, and easy to be attacked by the perpetrator or the terrorist. Therefore, railways public transportation requires activities and equipment that can prevent and protect their physicals, properties, and passengers and employees from the vulnerabilities. Although security system may not be able to entirely remove the 
risks of attack and threats on a public transportation system, good security measures can mitigate criminal activities and other hazardous incidents or make the attacks more complicated to be implemented, and enhance the probability to identify the wrongdoers or the perpetrators (Jenkins and Gersten, 2001). Strengthening security measures are the vital key to secure and control stations, terminals, and strategic areas of railways. The most appropriate way to restore security measure is to do a security assessment. There are many stakeholders involved in this process, and a passenger is a key person to help evaluate security measures because they look at the measures externally with their experience of using rail transport system service such as train, subway, elevated train, and rail link. A security assessment is considered as a process of ascertaining weaknesses and errors in physical structures, personal protection systems, security processes, etc. that might be exploited, and providing recommendations for removing and minimizing those areas of weaknesses (The Department of Veterans Affairs, 2000, p.9)

The State Railway of Thailand was allowed by the Thai cabinet to implement the construction of Suvarnabhumi Airport Rail Link and City Air Terminal project on June 1, 2004. The major objective of Suvarnabhumi Airport Rail Link and City Air Terminal is to provide transportation service for passengers who wish to make more comfortable, easier, and faster travel from downtown to the airport. The Rail Link system provides electric train with two service systems, which are Suvarnabhumi Airport Express (SA Express) and Suvarnabhumi City Line (SA City Line). The SA Express runs directly from downtown station to Suvarnabhumi Airport with the speed limit of 160 kilometers per hour while the SA City Line connects 8 stations from downtown station to the airport. The total distance of Suvarnabhumi Airport Rail Link service is 28 kilometers that goes through 8 stations with elevated platform. The passenger capacity per day is approximately 14,000 to 50,000 (Airport Rail Link, 2014a).

The primary challenging to Suvarnabhumi Airport Rail Link authorities is to ensure service quality delivered to the passengers whether or not its quality of service fulfils customers' expectations and needs. Security measures of Airport Rail Link is deemed to be part of service quality, and needed to be managed effectively to confirm safety and security of passengers and other stakeholders. In addition, based on research perspective, there are plenty of studies aimed at exploring service quality of Suvarnabhumi Airport Rail Link, yet investigating security measures assessment based on passengers' perception. Hence, the main objective of this present study is to identify the present level of security risk measures assessed by passengers of Suvarnabhumi Airport Rail Link. Also, this study's objective attempts to examine the differences of passengers according to their gender, marital status, age, educational level, and frequency of use in assessing security risk measures of Suvarnabhumi Airport Rail Link. This study places an emphasis on physical security measures that affect the personal security of passengers based on their perception. The results of this current study are to utilize for advantages of Suvarnabhumi Airport Rail Link security measures improvement and restoration. Consequently, research hypotheses are proposed as follows:

H1: Male passengers have a higher level of security measure of SuvarnabhumiAirport Rail Link than female passenger.

H2: There were statistically significant differences of passengers' marital status in assessing security measures of Suvarnabhumi Airport Rail Link.

H3: Passengers with different age groups have statistically significant differences in assessing security measures of Suvarnabhumi Airport Rail Link.

H4: Passengers with different level of education have statistically significant differences in assessing security measures of Suvarnabhumi Airport Rail Link.

H5: There were statistically significant differences of passengers' frequencies of using Airport Rail Link service in assessing security measures of Suvarnabhumi Airport Rail Link.

\section{Literature Review}

\subsection{Concept of Security and physical security}

Security is defined as protection to person, organization, property from attack, which can be classified to three distinctive types as follows: (Kurtus, 2001)

1) Attack on person refers to an attempt to assault or kill someone. In addition, attack on person includes hurting someone's feeling, causing an injury, and destroying a person's reputation.

2) Attack on property refers to an attempt in which properties and belongings are destroyed, ruined, or stolen.

3) Attack on organization refers to groups or people who intentionally aim at destroying or sabotaging prospective organizations, regardless of organization types. Terrorism is a good example of this type of attack.

The primary objective of physical security is to ensure access control and prevent the disruption of processes and 
operations. To attain these goals, the use of physical countermeasures such as lighting and fencing, electronic surveillance equipment, and security policies and procedures is implemented. However, these physical security control materials are one of various components of security systems, and may not be able to fully prevent the potential intruders or perpetrators from committing criminal activities. Thus, other approaches need to be executed along with these security control materials, especially the most effective element of security systems, which is the security assessment based on all stakeholders' perceptions to ensure that every aspect of physical security is covered to minimize intrusion and loss prevention, and to develop the perception of a safe and secure environment (SimplexGrinnell, 2014).

The concept of security implies that Suvarnabhumi Airport Rail Link service can be assaulted on three aspects, and caused the loss of tangible and intangible assets. Thus, security measures and practices of Suvarnabhumi Airport Rail Link must be reassured by conduction the security measures assessment to investigate that which areas are in needs of improvement and restoration based on passengers' perception.

\subsection{Security measures towards transportation system}

Jenkin and Gersten (2001) attempted to continue their study based on previous research on the best security practices for public surface transportation facilities. This study not only focused on security on public transportation in two targeted cities of terrorist attack - Tokyo and London, and also places an emphasis on security practice for public surface transportation facilities in two large cities in California - San Francisco Bay Area and Santa Clara Valley of California. This study found interesting information regarding security practices in London and Tokyo. For example, in London, the previous research by the government demonstrated that passengers on public transport were worried about their safety and security while waiting at stations. To reduce this trepidation, the major authorities had executed the Secure Stations Scheme, which encouraged Britain's rail companies to increase security measures at stations and reassured passenger safety. According to this plan, rail authorities were required to collect data from a passenger survey to determine whether passengers really feel safe at the stations. Moreover, rail authorities also are obligated to demonstrate quantifiable evidence of minimizing crime rates over a period of time. Best security practices for public surfaces transportation in Britain were exemplified in this study as well such as CCTV monitoring at stations, Emergency and information help points (Dedicated assistance area) at all station platforms, security guards both at the stations and on the trains, wellpositioned lighting and secure fencing, clear line of vision and security mirrors on platforms, and work in close cooperation with polices and local communities. This study recommended that good quality of information was critical to increase the safe journeys. If up-to-date information on service departures and interconnecting service provided accurately, passengers could plan their trips more safely.

Fink et al. (2005) scrutinized the developments of the U.S. transit security planning using two sources of data, which included in-depth interviews with officials from federal agencies and two transit agencies: a national transit industry organization, and local transit agencies, and a national survey of transit operators. The results indicated that transit security were still a priority for operators who were required to work to balance security needs with operations and management goals. Moreover, the study found that environmental design and public strategies and education had appeared to be more critical in transit security planning.

Promsri (2009) studied perception of customers towards security risk factors of subway system of Mass Rapid Transit Authority of Thailand (MRT). This study examined the customers' perception towards risk factors of physical security measure of subway. This research applied the concept of physical security management to develop the essentially relevant areas of physical security for mass transportation. These five areas of physical security management consisted of access control system, CCTV and VDO system, communication and public relations system, protective lighting system, and personal control and security guard system. Access control system refers to the protective measures to screen passengers prior to entering to public area of the terminal or station as well as accessing into the train. CCTV and VDO system refers to surveillance equipment that can deter potential criminal activities and to track records of any circumstances and occurrences. Communication and public relations system refer to emergency and regular information providing to passengers on the station and the train using electric speakers, Wi-Fi-system, Website, and TV and radio. Protective lighting system refers to well-positioned and proper amounts of lighting in the stations, the route to the station, the car parking, and on the train. Personal control and security guard system refers to availability and presence of security guards at the stations and on the trains. Five dimensions of physical security risk management were generated to a 25-item of Security Risk Assessment Questionnaire to measure security management of subway system of Mass Transit Authority of Thailand based on the concept of security. Samples of 411 passengers were collected data by using stratified sampling technique. Research hypotheses were measured using t-test, ANOVA, Pearson correlation, and multiple regressions. The findings of this study showed that the level of security of all four security risk factors were 
medium excluding the security level of electricity and light factor that was perceived in a high level. The relationships between all five security risk factors and socio-demographic characteristics were negatively significant at 0.01 level. In addition, findings also demonstrated the positive relationships between all five security risk factors and decisions of using of service factors in terms of frequency of using and reason of using the service at 0.01 level. The research suggested increasing security management procedures for MRTA security system, especially CCTV and VDO surveillance, and enhancing the number of security guards to ensure the standard of MRTA security management.

This present research applied the concept of security risk assessment discussed in Promsri's study (2009) as five dimensions of security risk assessment were appropriate to evaluate security measures of Suvarnabhumi Airport Rail Link because it had been used in measuring security practices in the public surfaces transportation in Thailand before.

\subsection{Safety and security practice of Suvarnabhumi Airport Rail Link}

According to Suvarnabhumi Airport Rail Link website (2014b), rules of using service that passengers need to comply with are noted as "Do's" and "Don'ts". Airport Rail Link recommends passengers comply with these following advices: "Stand well clear from the platform edge", "Stand behind the yellow tiles", "On the running train, please sit down or if necessary stand firmly and grab a pole", "Please follow instructions of our staff who guide you and stay with the group of at all times", and "Please mind the gap [between train and platform]". On the other hand, Airport Rail Link recommends passengers avoid doing the following things: "Don't go into the track area", "In station or on a train, don't play with or touch or open any equipment, there is a risk from electrocution", "Don't wander around alone", and "it is considered a construction site. Exercise care when you walk". These rules show safety and security practices of Suvarnabhumi Airport Rail Link in several dimensions, and encourage passengers to abide by these rules to ensure their safety and security while using Airport Rail Link service. However, other security measures and practices are not located on the website, and needed to be investigated through passengers' security assessment. Moreover, on the long holidays such as New Year's Day, Airport Rail Link enhances more security measures by increasing the numbers of security staff to ensure that passengers are safe and secured from any critical incidents that may occur during the journey.

\section{Research Methodology}

\subsection{Participants}

This study was used quantitative approach to describe the perception of passengers towards security measures of Suvarnabhumi Airport Rail Link service. The exact amount of population of passengers who used Airport Rail Link service was unknown, however; as stated on the Airport Rail Link website, the capacity of Airport Rail Link passengers was approximately 14,000 - 50,000 passengers per day. According to Krejcie and Morgan (1970), if the given population was about 50,000, which was the maximum capacity of passengers per day, the proper sample size should be determined at 381. Thus, data of this present study were gathered from 400 passengers who used Suvarnabhumi Airport Rail Link service. Data collection was taken in March - April, 2014 during 8 a.m. to 6 p.m. each day with the permission of Suvarnabhumi Airport Rail Link of Thailand. Respondents were asked for their permission to complete the questionnaire at the entrance of each station.

\subsection{Instrument}

A 25-item of Security Risk Assessment Questionnaire developed by Promsri (2009) was distributed to 400 passengers of Suvarnabhumi Airport Rail Link of Thailand by using systematic sampling technique (over time). There were three parts of this survey questionnaire as follows: 1) socio-demographic factors of respondents (checklist); 2) passengers' behaviors of using Airport Rail Link service (checklist); and 3) perceived security measures of Suvarnabhumi Airport Rail Link in five dimensions including access control system, CCTV and VDO system, communication and public relations system, protective lighting system, and personal control and security guard system (rating scale). Participants were asked to rate each item of this scale to the extent in which each physical security measures described Suvarnabhumi Airport Rail Link service properly according to their perceptions. The rating scales of Security Risk Assessment Questionnaire were $1=$ "strongly disagree", 2 = "disagree", 3 = "neither agree nor disagree", 4 = "agree", and 5 = "strongly agree. A high score on the scale indicated the high perception towards security measures or dimensions of Suvarnabhumi Airport Rail Link service. On the other hand, a low score on the scale designated the low perception towards the security measures of Suvarnabhumi Airport Rail Link service. To ensure validity of this instrument, factor analysis was used to determine the 
number of factors to remain. The factor loadings of this scale were from 0.304 to 0.892 , which were acceptable since the factor loading of each item was greater than 0.3. For the internal reliability, the scale had a Cronbach's alpha of 0.872 , which was highly acceptable.

The data were analyzed using the Statistical Package for the Social Sciences (SPSS Version 22.0 for Windows). Arithmetic Mean, standard deviation, independent t-test, and One-Way Analysis of Variance (ANOVA) were used to analyze data and test research hypotheses.

\section{Findings and Discussion}

Demographic factors of sample respondents indicated that the majority of respondents was female (63\%) with age between $21-30$ years (47\%). More than a half of them were educated at the undergraduate level $(66.5 \%)$. The majority of respondents were employees in a private company (64\%). For frequencies of using Airport Rail Link service, the results demonstrated that the largest group of respondents used Suvarnabhumi Airport Rail Link service approximately 4-5 days a week (40.8\%), the second largest group of passengers used Suvarnabhumi Airport Rail Link service one day per week (25.8\%), and $14.5 \%$ of these participants used Suvarnabhumi Airport Rail Link service approximately 2-3 days a week.

Table 1 showed five dimensions of security risk. The total mean score of perceived security measures was 3.56, which can be interpreted as a high level of security measures perception. Based on the findings, 'personal control and security guard system' factor received the highest meanscore $(\bar{x}=3.80$, S.D. $=.672)$ compared to other security measures. The second highest mean score was 'communication and public relation system' factor ( $\bar{x}=3.70$, S.D. $=.853$ ) following by 'CCTV and VDO system' ( $\bar{x}=3.59$, S.D. $=.859$ ), and 'access control system' ( $\bar{x}=3.39$, S.D. $=.832)$. The lowest mean score of these five security measures was 'protective lighting system' ( $\bar{x}=3.38$, S.D. $=.980)$. According to 'Access control system' factor, the results indicated two areas of improvement, which received the lowest score among 25 -item of this scale. The lowest scoring item of this factor was 'each station has a walk through metal protector to check passengers before entering to the station' ( $\bar{x}=2.17$, S.D. $=1.214$ ), and the second lowest scoring item was 'strictly check passengers' ( $\bar{x}=2.43$, S.D. $=1.282)$. For 'Protective lighting system' factor, the lowest scoring item was 'there are adequate lightings in the station' ( $\bar{x}=2.93$, S.D. $=1.239)$.

Table 1. Mean and Standard Deviation for Perceived Security Measures of Airport Rail Link Service $(n=400)$

\begin{tabular}{|l|c|c|c|c|}
\hline Security Measures & $\bar{x}$ & S.D. & Ranking & Level \\
\hline 1. Access control system & 3.39 & .832 & 4 & "High" \\
\hline 2. CCTV and VDO system & 3.59 & .859 & 3 & "High" \\
\hline 3. Communication and public relations system & 3.70 & .853 & 2 & "High" \\
\hline 4. Protective lighting system & 3.38 & .980 & 5 & "High" \\
\hline 5. Personal control and security guard system & 3.80 & .672 & 1 & "High" \\
\hline Total & 3.56 & .620 & & "High" \\
\hline
\end{tabular}

To compare mean differences of demographic variables, independent t-test analysis and analysis of variance (ANOVA) were used to compare the difference levels of perceived security measures of Thai passengers in terms of gender, marital status, age, education, and frequency of using services. Table 2 indicated that there was no significant difference between male and female passengers in evaluating security risk factors of Suvarnabhumi Airport Rail Link service as a whole ( $t=1.217, p=.224)$. Based on the results of each factor, the findings demonstrated no significant difference between male and female passengers. Due to the significant level achieved for this variable was greater than $0.05, H 1$ : male passengers have a higher level of security measures of Suvarnabhumi Airport Rail Link than female passenger, was rejected.

Table 2 Independent t-test for Security Measures of Airport Rail Link Service According to Gender $(n=400)$

\begin{tabular}{|c|c|c|c|c|c|c|}
\hline \multirow{2}{*}{ Security Measures } & \multicolumn{2}{|c|}{ Male $(n=148)$} & \multicolumn{2}{|c|}{ Female $(n=252)$} & \multirow{2}{*}{$\mathrm{t}$} & \multirow{2}{*}{ Sig. } \\
\hline & $\bar{x}$ & S.D. & $\bar{x}$ & S.D. & & \\
\hline Access control system & 3.57 & .757 & 3.40 & 874 & .446 & .656 \\
\hline CCTV and VDO system & 3.57 & .665 & 3.51 & .959 & .770 & .442 \\
\hline Communication and public relations system & 3.78 & .782 & 3.65 & .889 & 1.451 & .148 \\
\hline Protective lighting system & 3.50 & .984 & 3.31 & .973 & 1.865 & .063 \\
\hline Personal control and security guard system & 3.83 & .701 & 3.78 & 656 & .624 & .533 \\
\hline Total & 3.61 & .647 & 3.53 & .602 & 1.217 & .224 \\
\hline
\end{tabular}


Table 3 indicated that there was no significant difference between single and married passengers in evaluating security measures of Suvarnabhumi Airport Rail Link service as a whole $(t=-.886, p=.376)$. Based on the results of each factor, the findings demonstrated no significant difference between single and married passengers. Due to the significant level achieved for this variable was greater than $0.05, \mathrm{H2}$ : there were statistically significant differences of passengers' marital status in assessing security measures of Suvarnabhumi Airport Rail Link, was rejected.

Table 3. Independent t-test for Security Measures of Airport Rail Link Service According to Marital Status $(n=400)$

\begin{tabular}{|l|c|c|c|c|c|c|}
\hline \multirow{2}{*}{ Security Measures } & \multicolumn{2}{|c|}{ Single $(\mathbf{n}=\mathbf{2 6 8})$} & \multicolumn{2}{|c|}{ Married (n=132) } & \multirow{2}{*}{$\mathrm{t}$} & \multirow{2}{*}{ Sig. } \\
\cline { 2 - 6 } & $\bar{x}$ & S.D. & $\bar{x}$ & S.D. & & \\
\hline Access control system & 3.37 & .649 & 3.43 & 1.115 & -.731 & .465 \\
\hline CCTV and VDO system & 3.49 & .643 & 3.61 & 1.182 & -1.285 & .199 \\
\hline Communication and public relations system & 3.67 & .894 & 3.75 & .763 & -.898 & .370 \\
\hline Protective lighting system & 3.38 & .972 & 3.39 & 1.000 & -.085 & .933 \\
\hline Personal control and security guard system & 3.79 & .682 & 3.81 & .655 & -.275 & .784 \\
\hline Total & 3.54 & .593 & 3.60 & .671 & -.886 & .376 \\
\hline
\end{tabular}

Table 4 revealed statistically significant differences among passengers in different age groups relation to perceived security measures of Airport Rail Link service $(F=2.550, p=.027)$. Due to the significant level achieved for this variable was lower than 0.05, H3: passengers with different age groups have statistically significant differences in assessing security measures of Suvarnabhumi Airport Rail Link, was accepted. Pairwise comparisons were conducted for perceived security measures of Suvarnabhumi Airport Rail Link service because there was significant mean difference in this area of analysis.

Table 4. One-Way Analysis of Variance (ANOVA) for Security Measures of Airport Rail Link Service According to Age ( $\mathrm{n}$ $=400)$

\begin{tabular}{|c|c|c|c|c|c|}
\hline & Sum of Squares & df & Mean Square & F & Sig. \\
\hline Between Groups & 4.810 & 5 & .962 & 2.550 & $.027^{*}$ \\
\hline Within Group & 146.631 & 394 & .377 & & \\
\hline Total & 153.441 & 399 & & & \\
\hline
\end{tabular}

*Significant level at 0.05

Post-hoc LSD test of perceived security measures of Suvarnabhumi Airport Rail Link service revealed statistically significant differences between passengers aged between 21-30 years $)^{\bar{x}}=3.62$ ) and those who were Under 20 years ( $\bar{x}=3.44$ ), and employee aged between 51-60 years $(\bar{x}=3.22)$. Passengers aged between 21-30 years reported significantly higher perceived security measures of Suvarnabhumi Airport Rail Link service compared with passengers who were under 20 years and passengers who aged between 51-60 years. In addition, there were significant differences between passengers aged between 31-40 years $(\bar{x}=3.59)$ and those who were between $51-60$ years $(\bar{x}=3.22)$. Passengers aged 31-40 years reported significantly higher perceived security measures of Suvarnabhumi Airport Rail Link service compared with passengers who were between 51-60 years. There were no significant differences between the other groups (see Table 5).

Table 5. Pairwise Comparison for Perceived Security Measures of Airport Rail Link Service According to Age

\begin{tabular}{|c|c|c|c|c|}
\hline AGE $(\mathrm{I})$ & $(\mathrm{J})$ & $\begin{array}{c}\text { Mean Difference } \\
(\mathrm{I}-\mathrm{J})\end{array}$ & Std. Error & Sig. \\
\hline 21-30 years $(\bar{x}=3.62)$ & $\begin{array}{c}\text { Under 20 years }(\bar{x}=3.44) \\
51-60 \text { years }(\mathrm{M}=3.22)\end{array}$ & .18590 & .09416 & $.049^{\star}$ \\
& 51-60 years $(\bar{x}=3.22)$ & .37537 & .15995 & $.012^{\star}$ \\
\hline 31-40 years $(\bar{x}=3.59)$ & \multicolumn{1}{|c|}{$(16610$} & $.024^{*}$ \\
\hline
\end{tabular}

*Significant level at 0.05

Table 6 indicated that there were significant differences among passengers in different level of education relation to perceived security measures of Suvarnabhumi Airport Rail Link $(F=3.429, p=.033)$. Due to the significant level 
achieved for this variable was lower than 0.05, H4: passengers with different level of education have statistically significant differences in assessing security measures of Suvarnabhumi Airport Rail Link, was accepted. Pairwise comparisons were conducted for perceived security measures of Suvarnabhumi Airport Rail Link because there was significant mean difference in this area of analysis.

Table 6. One-Way Analysis of Variance (ANOVA) for Security Measures of Airport Rail Link ServiceAccording to Educational Level $(n=400)$

\begin{tabular}{|l|c|c|c|c|c|}
\hline & Sum of Squares & df & Mean Square & F & Sig. \\
\hline Between Groups & 2.605 & 2 & 1.303 & 3.429 & $.033^{\star}$ \\
\hline Within Group & 150.836 & 397 & .380 & & \\
\hline Total & 153.441 & 399 & & & \\
\hline
\end{tabular}

*Significant level at 0.05

Post-hoc LSD test of perceived security measures of Suvarnabhumi Airport Rail Link service revealed statistically significant differences between passengers who had undergraduate degree $(\bar{x}=3.60)$ and those who had graduate degree level $(\bar{x}=3.32)$. Passengers with undergraduate degree level reported significantly higher perceived security measures of Suvarnabhumi Airport Rail Link service compared with passengers with graduate degree level. There were no significant differences between the other groups (see Table 7).

Table 7. Post-hoc LSD test for Perceived Security Measures of Airport Rail Link Service According to Education

\begin{tabular}{|c|c|c|c|c|}
\hline Education (I) & $(\mathrm{J})$ & Mean Difference (I-J) & Std. Error & Sig. \\
\hline $\begin{array}{c}\text { Undergraduate } \\
(\bar{x}=3.60)\end{array}$ & $\begin{array}{c}\text { Graduate } \\
(\bar{x}=3.32)\end{array}$ & .27925 & .10690 & $.009^{\star}$ \\
\hline
\end{tabular}

*Significant level at 0.05

Table 8 indicated that there were significant differences among passengers in terms of frequencies of using service relation to perceived security measures of Suvarnabhumi Airport Rail Link ( $F=5.115, p=.002)$. Due to the significant level achieved for this variable was lower than $0.05, H 5$ : there were statistically significant differences of passengers' frequencies of using Suvarnabhumi Airport Rail Link service in assessing security measures of Suvarnabhumi Airport Rail Link, was accepted. Pairwise comparisons were conducted for perceived security measures of Suvarnabhumi Airport Rail Link because there was significant mean difference in this area of analysis.

Table 8. One-Way Analysis of Variance (ANOVA) for Security Measures of Airport Rail Link ServiceAccording to Frequencies of Using Services $(n=400)$

\begin{tabular}{|l|c|c|c|c|c|}
\hline & Sum of Squares & df & Mean Square & F & Sig. \\
\hline Between Groups & 5.724 & 3 & 1.908 & 5.115 & $.002^{*}$ \\
\hline Within Group & 147.717 & 396 & .373 & & \\
\hline Total & 153.441 & 399 & & & \\
\hline
\end{tabular}

*Significant level at 0.05

Post-hoc LSD test of perceived security measures of Airport Rail Link service revealed statistically significant differences between passengers who used Suvarnabhumi Airport Rail Link 2-3 days a week ) $\bar{x}=3.58$ ) and those who used service one day a week $(\bar{x}=3.37)$. Passengers used service 2-3 days a week reported significantly higher perceived security measures of Airport Rail Link service compared with passengers who used Suvarnabhumi Airport Rail Link one day a week. In addition, there were significant differences between passengers who used Suvarnabhumi Airport Rail Link 4-5 days a week $(\bar{x}=3.60)$ and those who used one day a week $(\bar{x}=3.37)$. Passengers travelled with Suvarnabhumi Airport Rail Link 4-5 days a week reported significantly higher perceived security measures of Suvarnabhumi Airport Rail Link service compared with passengers who travelled one day a week. Furthermore, results showed statistically significant differences between passengers who took Suvarnabhumi Airport Rail Link more than 5 days a week and those used only one day a week. Passengers travelled more than 5 days a week reported significantly higher perception of security measures of Suvarnabhumi Airport Rail Link service compared to those who used only one day a week. There were no 
significant differences between the other groups (see Table 9).

Table 9. Post-hoc LSD test for Perceived Security Measures of Airport Rail Link Service According to Frequency of Using Service

\begin{tabular}{|c|c|c|c|c|}
\hline Frequency of Using Service (I) & $(\mathrm{J})$ & Mean Difference $(\mathrm{I}-\mathrm{J})$ & Std. Error & Sig. \\
\hline $\begin{array}{c}2-3 \text { days a week } \\
(\bar{x}=3.58)\end{array}$ & $\begin{array}{c}\text { One day a week } \\
(\bar{x}=3.37)\end{array}$ & .20774 & .10026 & $.039^{\star}$ \\
\hline $\begin{array}{c}4-5 \text { days a week } \\
(\bar{x}=3.60)\end{array}$ & $\begin{array}{c}\text { One day a week } \\
(\bar{x}=3.37)\end{array}$ & .22905 & .07688 & $.003^{*}$ \\
\hline $\begin{array}{c}\text { More than } 5 \text { days a week } \\
(\bar{x}=3.71)\end{array}$ & $\begin{array}{c}\text { One day a week } \\
(\bar{x}=3.37)\end{array}$ & .34133 & .09236 & $.000^{\star}$ \\
\hline
\end{tabular}

*Significant level at 0.05

\section{Conclusion and Recommendations}

Overall, the results of this study indicated that personal control and security guard system received the highest score for security measures assessment, which means that Suvarnabhumi Airport Rail Link has had enough numbers of security staff both at stations and on trains to monitor the safety and security of passengers. Findings of this study were new knowledge in this area of study as there had been no study focusing on security measures of Airport Rail Link in Thailand before. Analysis of independent t-test analysis showed no significant mean differences between male and female passengers and for marital status in evaluating security measures of Suvarnabhumi Airport Rail Link service. This means that gender and marital status did not affect the perception on security measures of Airport Rail Link. Analysis of variance (ANOVA) revealed statistically significant differences at 0.05 level among passengers in different age groups, educational levels, and frequencies of using service to perceived security measures of Suvarnabhumi Airport Rail Link service. This means that the older passengers are more likely to perceived security practices of Airport Rail Link that affect their safety and security when travel to the journeys than the younger ones. Also, a higher academic level, the more attention paid on security measures as passengers with higher knowledge are more aware of travel environment while using Airport Rail Link. Moreover, passengers who frequently used Airport Rail Link service were more likely to better investigate the security measures and practices than passengers who seldom travelled by Airport Rail Link. This means that they gradually observed the environment and recognized some security measures provided at the stations or on the trains when travelled to the destinations.

Recommendations for research implementations for Suvarnabhumi Airport Rail Link of Thailand were to install Xray equipment (Walk Through Metal Protector) as a detective assistance for security management, and to strictly check passengers when enter to the Suvarnabhumi Airport Rail Link terminal or station.Additionally, although the overall score of security measures assessment was in "high" level, Suvarnabhumi Airport Rail Link should increase some areas of security practices in particular protective lighting system, which was perceived the lowest level among the five dimensions. Thus, Airport Rail Link authorities should pay more attention on the lighting system especially the adjustment of lighting position in some areas at the stations at the night time to increase passengers confidence when travel after dark. There were some limitations in this study. The demographic variables and passengers' behaviors of using Airport Rail Link variables were limited only some variables. Other variables especially passenger's behaviors of using Airport Rail Link service should be scrutinized in a further study. Other security measures should be studies in the future. Evaluating security measures and practices from the perception of Airport Rail Link employees should be explored for a further study. The comparisons of security measures and practices among rail transit systems in Thailand such as skytrain (BTS), subway (MRT), and Suvarnabhumi Airport Rail Link are also recommended for a further study.

\section{Acknowledgement}

I would like to show my appreciation to the support of Rajamangala University of Technology Phra Nakhon for providing graduate students to help for data collection process. 


\section{References}

Airport Rail Link. (2014a). About the project.Retrived on April 18, 2014 from http://www.srtet.co.th/en/10_footer/02_about_us.html Airport Rail Link. (2014b). Rules.Retrived on April 18, 2014 from http://www.srtet.co.th/en/09_rule/09_rule.html

Armstrong, N. J., Bland, D., Cox, E., Oddo, E., Wears, D., \&Zai, P. C. (2008). Securing America's passenger rails: Analyzing current challenges and future solutions. Retrieved on April 25, 2014 from http://insct.syr.edu/wp-content/uploads/2013/02/SecuringAmericas-Passenger-Rails.pdf

Fink, C., Taylor, B. D., \&Loukaitou-Sideris, A. (2005). From policy and response to system design and operations: Inter-governmental transit security planning in the U.S. Journal of Public Transport. 8(4) Retrieved on April 25, 2014 from http://www.nctr.usf.edu/wpcontent/uploads/2010/03/JPT-8-4S-Fink.pdf

Jenkins, B. \& Gersten, L. (2001).Protecting public surface transportation against terrorism and serious. Retrieved on April 22, 2014 from http://www.fta.dot.gov/documents/terrorism_final.pdf

Krejcie, R. V. \& Morgan, D. W. (1970). Determining sample size for research activities. Educational and Psychological Measurement, 30, 607-610.

Kurtus, R. (2001), Theory of security. Retrieved on March 12, 2014 from http://www.school-for-champions.com/security/theory_of_ security.htm\#.U2ORxbY5Prc

Passengerfocus.(2009). Passenger perceptions of personal security on the railways.Retrieved on April 20, 2014 from http://www.transportscotland.gov.uk/files/documents/public-transport/PVS/Passenger_Perceptions_on_Personal_Security.pdf

Promsri, C. (2009). Perceived security risk factors of the subway system of the Mass Rapid Transit Authority of Thailand. $\overline{H C U}_{\text {Journal of }}$ Social Science and Humanities, 13(25). [Thai language].

SimplexGrinnell. (2014). Physical security concepts. Retrieved on April 20, 2014 from http://www.simplexgrinnell.com/SiteCollection Documents/Training/PACEBook2.pdf

The Department of Veterans Affairs. (2002). Physical security assessment for Department of Veterans Affairs facilities: Recommendations of the National Institute of Building Sciences Task Group. Retrieved on April 20, 2014 from http://www.cfm.va.gov/til/physicalSecurity/VAPhysicalSecurityReportNIBS20020906.pdf

U.S. General Accounting Office. (2003). Transportation security: Federal action needed to help address security challengers, GAO-03843. Washington, D.C: GAO. 